\title{
THE LONGEVITY OF CROP SEEDS STORED UNDER LONG-TERM CONDITION IN THE NATIONAL GENE BANK OF BULGARIA
}

\author{
GERGANA DESHEVA \\ Institute of Plant Genetic Resources “Konstantin Malkov”, Sadovo, Bulgaria
}

DESHEVA, G.: The longevity of crop seeds stored under long-term condition in the National gene bank of Bulgaria. Agriculture (Pol'nohospodárstvo), vol. 62, 2016, no. 3, p. 90-100.

\begin{abstract}
Seed accessions from 7 plant families and 28 species stored for above 20 years in the National gene bank of Bulgaria were evaluated. All seed accessions were maintained as base collection under long-term storage conditions with low moisture contents $(5 \pm 2 \%)$ in hermetically closed containers at $-18^{\circ} \mathrm{C}$. On the basis of experimental data, the seed storage characters $\sigma$ (standard deviation of seed death in storage), $\mathrm{P}_{50 \%}$ (the time for viability to fall to $50 \%$ ) and $\mathrm{P}_{10 \%}$ (the time for viability reduction of $10 \%$ ) were determined allowing the prediction of seed storage life and the regeneration needs. The results showed significant differences in loss of seed viability among species and within the species. After 20-24 years of storage, eleven crops showed minimal viability decline under 5\% as compared to the initial viability (oats, barley, maize, bread wheat, durum wheat, smooth brome grass, faba bean, chickpea, sunflower, cucumber and pepper). For the same storage time, another group of crops (sorghum, triticale, orchard grass, tall fescue, common vetch, grass pea, lentil, common bean, rapeseed, tobacco, flax, cabbage and tomatoes) presented 5-10\% reduction of seed viability. More significant changes in seed viability - above $10 \%$ - were detected for peanuts, lettuce, soybean and rye. The $\sigma$ values varied from 20.41 years (Arachis hypogaea L.) to 500 years (for Avena sativa L. and Triticum aestivum L). There was wide variation across species, both in time taken for the viability to fall to $50 \%$ and in time taken for the seed viability reduction of $10 \%$. The study illustrates the positive effect of both seed storability early monitoring and prediction of regeneration needs as a tool for limiting undesired losses.
\end{abstract}

Key words: gene bank, long-term storage, seed germination, seed longevity, seed viability

The ex situ conservation of plant genetic resources in seed gene banks play an important role for food security in the future. Seed gene banks maintain genetic resources of the seeds over decades or centuries. They are an efficient and cost-effective way of conserving large amounts of genetic diversity (Waldren et al. 2000) as many thousands of seed collections representing different populations or plant taxa can be housed in a small area (Walsh et al. 2003). The initial viability of the seeds, seed moisture content and its interaction with relative humidity of the air and the storage temperature have significant influence on seed longevity (Roberts 1973). Even in seeds stored under optimal conditions suitable for long-term storage, viability may decrease as a result of deterioration processes (Sastry et al.
2008). Seed viability declines slowly at first, and then rapidly as seeds age (Roberts \& Ellis 1982). Accordingly, it is important to know when this decline occurs so that the accession can be regenerated by replacing the exiting seeds with ones having high-viability (Ho-Sun et al. 2013). The Genebank Standards for Plant Genetic Resources for Food and Agriculture (2014) recommended the initial viability test be conducted as early as possible, before the seeds are packaged and enter the storage, and subsequent tests are determined at certain intervals during the storage. Viability monitoring test intervals can be set at one-third of the time predicted for viability to fall to 85 percent of initial viability or lower, depending on the species or specific accessions, but no longer than 40 years. If this deterioration pe- 
riod cannot be estimated, the interval is ten years for species expected to be long-lived and five years or less for species expected to be short-lived. It is recognized that viability monitoring is an expensive activity, and that gene bank curators wish to seek cost-cutting procedures.

Seed longevity is defined as seed viability after seed dry storage (storability), and therefore, describes the total seed life span (Rajjou \& Debeaujon 2008). This storability period includes both dormant and non-dormant stages. During seed storage, seeds deteriorate, lose vigour, and as a result, become more sensitive to stresses during germination, and ultimately die. The rate of this aging depends on the seed moisture content, temperature, and initial seed quality (Walters 1998; Walters et al. 2005a). Seed longevity is a quantitative trait for which variation is present among naturally occurring accessions (ThuPhuong et al. 2012). Understanding the differences in seed longevity in various species is therefore crucial to the effective management of seed conservation collections because it underpins the selection of viability re-test intervals, and hence regeneration or re-collection strategies (Probert et al. 2009; Groot et al. 2015).

The National Gene bank of Bulgaria was built in 1984 and carries out a scientific program for the long-term preservation of germplasm with seeds under controlled conditions, in accordance with the standards developed by FAO (1994/2014). The gene bank facilities are designed both for long-term storage and medium-term storage. There are 59,292 preserved seed accessions from 63,713 totally registered plant germplasms in the country (http://eurisco.ecpgr.org), where $72 \%$ are under long-term storage conditions $(42,699$ accessions $)$.

The aim of this study was to evaluate the effect of the long-term gene bank storage from a practical point of view for the 28 plant species maintained for more than 20 years according to the recommended dry conditions and cold temperature.

\section{MATERIALS AND METHODS}

\section{Seed material}

A total of 5,876 seed accessions from 7 plant families and 28 species (Poaceae - Avena sativa L.,
Bromus inermis L., Festuca arundinacea Schreb., Hordeum vulgare L., Secale cereale L., Sorghum vulgare L., X Triticosecale Wittm., Zea mays L., Triticum aestivum L., Triticum durum Desf., Dactylis glomerata L., Fabaceae - Vicia faba L., Vicia sativa L., Lathyrus sativus L., Cicer arietinum L., Arachis hypogaea L., Lens esculenta L., Phaseolus vulgaris L., Glycine max Merr., Solanaceae - Capsicum annuum L., Lycopersicon esculentum Miller, Nicotiana tabacum L., Brassicaceae - Brassica napus L., Brassica oleracea L., Asteraceae - Helianthus annuus L., Lactuca sativa L., Cucurbitaceae - Cucumis sativus L., Linaceae - Linum usitatissimum L.) stored since 1981-1991 in the National Genebank of Bulgaria were evaluated. All seed accessions were maintained as base collections under long-term storage conditions with low moisture contents $(5 \pm 2 \%)$ in hermetically closed containers (glass jars or three laminated aluminium foil packets) at $-18^{\circ} \mathrm{C}$.

\section{Seed viability}

Seed viability was detected on the basis of germination rate of accessions in storage. The recurring seed germination was determined at regular intervals: just before the storage, and periodically every following 10 years (i.e., 10 and 20 years, respectively). The germination tests of target plant species were carried out according to ISTA rules (ISTA 1985). The recommendations for work in the gene banks (Ellis et al. 1985a; 1985b; Hanson 1985) were also implemented. Seeds stored at $-18^{\circ} \mathrm{C}$ for about 10 and 20 years, respectively, were pre-conditioned before these were set to germinate: equilibration of seed containers at room temperature for 24 hours was followed by re-humidification of seeds, as described earlier (Stoyanova 2001).

\section{Seed moisture content}

The moisture content of seed accessions, both before and after the time of storage, was determined using oven methods of ISTA (1985) for reduced working sample (about 1-3 g per accession).

\section{Data analysis}

The Probit analysis for modelling of data from seed storage experiments was used according to the models first described by Roberts (1973). It was based on a straight line relationship between viabil- 
ity and storage period. The slope of this line was the value of $\sigma$ and the intercept was the (theoretical) initial viability of seeds $\mathrm{K}_{\mathrm{i}}$ (Ellis \& Roberts 1980). The relationship used for calculation was:

$$
v=\mathrm{K}_{\mathrm{i}}-\mathrm{p} / \sigma,
$$

where: v was the viability in Probit after p years in storage.

Seed longevity is described by storage constants $\mathrm{P}_{50}$ and $\mathrm{P}_{10}$ according to Ellis and Roberts (1980), where $\mathrm{P}_{50}$ is the time for viability to fall to $50 \%$ and $\mathrm{P}_{10}$ is the time for viability reduction of $10 \%$.

The information for seed accessions in storage was maintained as ACCESS-database. The raw data files were used for statistical analysis by analysis of variance (ANOVA) and LSD test using IBM SPSS Statistics 19.

\section{RESULTS}

Maintenance of seed germination in different crops

\section{Cereals}

In the group of cereals, 4,138 seed accessions from eight species were evaluated (Table 1). Minimal changes of seed quality under storage were detected for four species: barley, oats, maize and wheat. Here, no significant differences were examined between seed germinations at the beginning of storage and after a significant time of storage, in both first control test (with storage time of 10-14 years) and second control test (with storage time of 20-24 years). However, it should be pointed out that as presented in a previous research, the rate of difference before and after the storage influenced the mean value of seed germination, and also had a stronger effect on the standard deviation (Stoyanova 2001).

Another group of cereals was more significantly affected by storage: rye, sorghum and triticale. As presented, the decline of mean seed germination for rye accessions was from $94.57 \%$ to $85.51 \%$ after 12.94 years and to $83.68 \%$ after 23.48 years. The mean germination percentages of sorghum and triticale after $10-14$ years of storage dropped by about $10 \%$ in comparison with the mean initial germination values. The seed germination rate of these three species after the second control test remained about $82-83 \%$.
The rate of variation between species was illustrated by differences of standard deviations calculated for the mean values of germination after storage. But the difference was more significant in the cases with larger variations between minimum and maximum values and a considerable reduction in seed germinability.

\section{Cereal grasses}

Grass seeds included in the study belong to three plant species were Bromus inermis L., Dactylis glomerata L. and Festuca arundinacea Schreb. An inappreciable loss of viability occurred after 10-14 years of storage for Dactylis glomerata L. and Festuca arundinacea Schreb., and an unnoticeable increase in seed germination for Bromus inermis L. After 20-24 years of storage, the mean germination values of Dactylis glomerata L. and Festuca arundinacea Schreb. decreased more than 5\% as compared to the initial germination percentages. Their SDs increased significantly from \pm 6.39 to $\pm 12.18 \%$ and from \pm 5.29 to $\pm 10.30 \%$, respectively (Table 1 ).

\section{Legumes}

Seed accessions from eight species were evaluated. Two species - Vicia faba L. and Cicer arietinum L. - preserved high mean germination values after the first and second control tests. Practically no significant difference in comparison to initial germination percentages was assessed for both species. The highest decrease of viability was recorded for Arachis hypogaea L. and Glycine max Merr. After 13.77 years of storage, the germination of peanut seeds declined from $91.96 \%$ to $69.96 \%$, while after 22.35 years of storage, from $91.96 \%$ to $63.07 \%$. The SDs increased from $\pm 6.67 \%$ to $\pm 16.56 \%$ and $\pm 18.35 \%$, respectively. The seed germination of soybean accessions also decreased significantly - above 10\% in relation to initial value. Other legumes (Vicia sativa L., Lathyrus sativus L., Lens esculenta L. and Phaseolus vulgaris L.) showed slower reduction in mean value of germination (with $7.81 \%, 7.14 \%$, $5.22 \%$ and $7.68 \%$, respectively) after $21-24$ years of storage (Table 1).

\section{Industrial crops}

Four species were tested in this group. The average germination rate of Brassica napus seeds in the 
beginning of storage was $94.72 \%$. Subsequently, at the first control test after 13.27 years, it decreased to $85.79 \%$ and retained almost the same until the second control test. The seeds of Helianthus annuus were preserved with minimal changes. A slow drop of seed germination of Nicotiana tabacum was observed after 13 years of storage but the second control test presented a more significant decrease to about $90-91 \%$. The value of standard deviation in both test cases for tobacco seeds increased, indicating variation in a large scale between accessions. For Linum accessions, a decrease in seed germination from the beginning of storage up to first control test was observed, maintaining the value to the second test. The tested seed accessions were preserved with no significant changes for more than 20 years (Table 1).

\section{Vegetables}

The vegetable seeds included in the study belonged to five plant species. Cucumber and pepper seeds showed no significant change in germination percentage after more than 20 years of storage. In contrast, viability of lettuce seeds decreased from $85.18 \%$ to $75.83 \%$ after 13.40 years and to $72.40 \%$ after 22.37 years of storage. The SDs increased from $\pm 8.81 \%$ to $\pm 11.60 \%$ and $\pm 14.20 \%$, respectively. The mean germination percentage of tomato seeds dropped by $7.16 \%$ after 11.30 years of storage. There was no further significant decrease in the following years in the second control test. The value of SD between both the tests was in the same range. The viability of Brassica oleracea L. after 22.64 years of storage also decreased significantly by $7.15 \%$.

\section{Monitoring of seed viability and longevity}

Results from the assessment of Probit longevity for 28 plant species under real long-term storage condition are presented in Table 2. The parameters estimated were $\mathrm{K}_{\mathrm{i}}$ (Probit value of initial seed viability), $1 / \sigma$ (measure of seed deterioration in storage), $\sigma$ (standard deviation of seed death in storage), $\mathrm{P}_{50 \%}$ (seed half-life or measure of time to $50 \%$ seed viability in storage) and $\mathrm{P}_{10 \%}$ (time in years for seed viability reduction with $10 \%$ ).

The highest $\mathrm{K}_{\mathrm{i}}$ value (2.39) was recorded for Cucumis sativus L., while rate of seed deterioration
$(1 / \sigma)$ was the highest for Arachis hypogaea L. $(-0.049)$ and the lowest for Avena sativa L. and Triticum aestivum L. (-0.002). The $\sigma$ values varied from 20.41 years (Arachis hypogaea L.) to 500 years for Avena sativa L. and Triticum aestivum L. Nineteen plant species had $\sigma$ values under 100 years $(\sigma<100$ years), five species between 100 and 300 years $(100<\sigma<300)$ and only oats, barley, bread wheat and sunflower had values above 300 years $(300<\sigma<1000)$. There was a wide variation across species in both the time taken for viability to fall to $50 \%$ and the time for seed viability reduction by $10 \% . \mathrm{P}_{50 \%}$ ranged between 28.51 years for Arachis hypogaea L. to 880 years for Avena sativa $\mathrm{L}$. (Table 2). The safe storage time $\left(\mathrm{P}_{10 \%}\right)$ was between 9 to 20 years for peanut, soybean and lettuce, and 318.5 and 338.5 years for bread wheat and oats, respectively.

\section{DISCUSSION}

It is very important that seeds stored in the gene bank are capable of producing plants when sown in the field. They must have high viability at the start of the storage, and maintain it during storage. Seeds with a high initial viability will also survive longer in storage. The seed initial germination percentage in the National Genebank of Bulgaria should be above $80 \%$, which is the lowest viability standard for seed accessions to be included in the long-term storage (Stoyanova 2001). Good seed storage conditions maintain germplasm viability, but even under excellent conditions, viability declines with storage duration (Walters et al. 2005b). Seed ageing or seed deterioration is commonly described as the loss of seed quality or viability over time (Coolbear 1995). Therefore, gene banks need to assess the viability periodically to detect the loss in viability during storage before it falls below the threshold for regeneration (Chin 1994). Seed viability is determined through germination tests before seeds are packaged and placed in the gene bank storage room, and this serves as a reference point for subsequent periodic viability checks during storage (Smith et al. 2003; FAO 2014).

In this study, the viability after $10-14$ and $20-24$ years of storage were assessed among 28 crop species. The results showed that there were signifi- 
cant differences in the loss of seed viability among species and within the species. Eleven crops (oats, barley, maize, bread wheat, durum wheat, smooth brome grass, faba bean, chickpea, sunflower, cucumber and pepper) showed relatively stable storage after 20-24 years, as indicated by the respective declines in the viability under $5 \%$. Sorghum, triticale, orchard grass, tall fescue, common vetch, grass pea, lentil, common bean, rapeseed, tobacco, flax, cabbage and tomatoes presented $5-10 \%$ declines in viability, while peanuts, lettuce, soybean and rye showed above $10 \%$ after $20-24$ years of storage (Table 1).

From the germination results obtained after 10-14 years of storage, some species as Avena sativa L., Hordeum vulgare L., Dactylis glomerata L. and Bromus inermis L. showed slow increase in the germination percentages from initial values, and except for Dactylis glomerata L., an insignificant decrease in the rates after 20-24 years of storage. The increase in germination after storage relates to post-harvest dormancy (Ruiz et al. 1999; Stoyanova 2001; Walsh et al. 2003; Pérez-García et al. 2009).

When comparing the initial germination percentages with results from the first control test (10-14 years of storage), other crops as rye, triticale, rapeseeds, flax, lettuce and tomatoes showed a significant decrease in the germination rate ranging between 6 and $10 \%$. However, when comparing the results between first and second control tests, there were no significant changes.

Seeds of species as peanut and soybean are characterized as short-lived (Copeland \& McDonald 2001; Stoyanova 2001; Walters et al. 2005b). In this study, they showed the largest reductions in viability after first and second retests.

In some leguminous seeds, the second test exceeded the seed germination from the first test. The cause for this was that in the past, the hard seeds in the germination test were described as 'non-germinating'. Some changes in the viability may have also been the results of different degrees of operator error, as the staff performing the germination test changed over time.

According to $\mathrm{Lu}$ et al. (2004), the genetic characteristics of species and pre-storage environments are the main factors for seed viability decline. Adverse climate at the stages of seed ripening and harvesting, as well as the damage caused by seed-extraction, drying and transportation after harvest could affect the rate of seed viability decline during storage (Sai Babu et al. 1983).

From a practical point of view, it is important to be able to predict the appropriate frequency of control tests in the gene bank. The determination of the maximum storage period for each material in particular conditions of each seed bank is of great importance in designing management guidelines that minimize viability controls and regeneration/multiplication of the samples (Pita et al. 1998; Probert et al. 2009). Regeneration is a costly gene bank operation, and may also negatively affect the genetic integrity of an accession through exposure to the influence of genetic drift, selection, contamination and human error (Parzies et al. 2000; Benkova \& Zakova 2008; Fu et al. 2015). Therefore, it is important to maximize seed longevity and keep operational costs and logistics manageable through the monitoring of seed deterioration, an essential task for managing stored germplasm (Engels \& Visser 2003).

The measure of seed longevity in this study is based on the $\sigma$ value (standard deviation of seed death in storage), defining the period during which the percentage viability is reduced by one Probit as described by Hong et al. (1998). According to Ellis and Roberts (1980), the life span of a seed-lot, the time until all the seeds have lost viability, depends on the value of $\sigma$ and on the proportion of the seeds which are viable at the start of the storage, $\mathrm{K}_{\mathrm{i}}$ (in Probit). The seed longevity varies among families, species, genotypes, seed lots, and even among individual seeds inside the same bag and depends on the storage conditions (Walters et al. 2005b; Nagel et al. 2009; Probert et al. 2009; Nagel \& Börner 2010; Nagel et al. 2010; van Treuren et al. 2013; Ho-Sun et al. 2013). In our study $\sigma$ value varied from 20.41 to 500 years. It was the lowest for Arachis hypogaea L. (20.41 years) and the highest for Avena sativa L. and Triticum aestivum L. (500 years). Grain legumes, except chickpea, were characterized with a short life span $(\sigma<100$ years) (Stoyanova 2001). The seeds of bread wheat, oats, barley and sunflower were found to have the longest storability $(\sigma>300$ years). The predicted longevity was 111.11 years for Triticum durum Desf., Dactylis glomerata L., Cicer arietinum L. and Capsicum annuum 
$\mathrm{T}$ a

Changes in the seed viability values of plant species during the storage period in the National Gene bank of Bulgaria

\begin{tabular}{|c|c|c|c|c|c|c|c|}
\hline Crops/Species & $\begin{array}{l}\text { Number of } \\
\text { access. }\end{array}$ & $\begin{array}{c}\text { Initial seed } \\
\text { germination } \\
{[\%]}\end{array}$ & $\begin{array}{c}\text { Storage } \\
\text { period to } \\
\text { the first } \\
\text { control } \\
\text { test } \\
\text { [year] }\end{array}$ & $\begin{array}{c}\text { Mean value of } \\
\text { germination in } \\
\text { the first control } \\
\text { test } \pm \text { SD }[\%]\end{array}$ & $\begin{array}{l}\text { Storage } \\
\text { period } \\
\text { from first } \\
\text { to second } \\
\text { control test } \\
\text { [year] }\end{array}$ & $\begin{array}{c}\text { Mean value of } \\
\text { germination } \\
\text { in the second } \\
\text { control test } \pm \text { SD } \\
{[\%]}\end{array}$ & $\begin{array}{c}\text { Total } \\
\text { storage } \\
\text { period } \\
\text { [year] }\end{array}$ \\
\hline \multicolumn{8}{|c|}{ Cereals } \\
\hline Avena sativa $\mathrm{L}$. & 457 & $95.76 \pm 6.08$ & 12.94 & $96.59 \pm 5.74$ & 10.18 & $95.28 \pm 7.34$ & 23.12 \\
\hline Hordeum vulgare L. & 1195 & $93.22 \pm 5.46$ & 14.28 & $93.40 \pm 6.04$ & 8.50 & $91.99 \pm 6.19$ & 22.78 \\
\hline Secale cereale $\mathrm{L}$. & 35 & $94.57 \pm 5.18$ & 12.94 & $85.51 \pm 4.84^{+++}$ & 10.54 & $83.68 \pm 7.71^{+++}$ & 23.48 \\
\hline Sorghum vulgare L. & 99 & $91.39 \pm 6.37$ & 10.72 & $80.41 \pm 18.85^{++}$ & 13.41 & $83.63 \pm 17.35^{++}$ & 24.13 \\
\hline X Triticosecale Wittm. & 52 & $92.00 \pm 6.48$ & 11.67 & $82.62 \pm 12.98^{++}$ & 12.33 & $82.03 \pm 16.50^{++}$ & 24.00 \\
\hline Zea mays L. & 364 & $94.60 \pm 5.54$ & 12.30 & $90.31 \pm 8.75$ & 11.19 & $91.19 \pm 9.26$ & 23.49 \\
\hline Triticum aestivum $\mathrm{L}$. & 1547 & $95.51 \pm 4.99$ & 13.70 & $95.11 \pm 5.12$ & 9.33 & $94.97 \pm 4.82$ & 23.03 \\
\hline Triticum durum Desf. & 389 & $95.37 \pm 5.54$ & 11.42 & $94.12 \pm 7.10$ & 15.87 & $92.58 \pm 7.22$ & 27.29 \\
\hline \multicolumn{8}{|c|}{ Cereal grasses } \\
\hline Dactylis glomerata $\mathrm{L}$. & 55 & $83.81 \pm 6.39$ & 11.83 & $84.36 \pm 5.94$ & 10.95 & $78.4 \pm 12.18^{++}$ & 22.78 \\
\hline Bromus inermis L. & 37 & $89.83 \pm 6.15$ & 13.45 & $90.37 \pm 5.86$ & 7.68 & $87.83 \pm 5.27$ & 21.13 \\
\hline $\begin{array}{l}\text { Festuca arundinacea } \\
\text { Schreb. }\end{array}$ & 34 & $96.23 \pm 5.29$ & 13.23 & $92.26 \pm 10.41$ & 9.74 & $89.52 \pm 10.30^{++}$ & 22.97 \\
\hline \multicolumn{8}{|c|}{ Legumes } \\
\hline Vicia faba $\mathrm{L}$. & 57 & $95.68 \pm 5.99$ & 13.35 & $94.64 \pm 7.20$ & 8.59 & $92.45 \pm 7.18$ & 21.94 \\
\hline Vicia sativa $\mathrm{L}$. & 131 & $91.94 \pm 7.50$ & 10.45 & $81.39 \pm 9.39^{+++}$ & 13.71 & $84.12 \pm 12.47^{++}$ & 24.16 \\
\hline Lathyrus sativus L. & 65 & $94.81 \pm 4.40$ & 11.24 & $85.30 \pm 7.33^{+++}$ & 12.51 & $87.67 \pm 7.48^{+++}$ & 23.75 \\
\hline Cicer arietinum L. & 37 & $94.48 \pm 6.34$ & 12.59 & $89.59 \pm 5.96$ & 11.32 & $91.72 \pm 5.36$ & 23.91 \\
\hline Arachis hypogaea L. & 54 & $91.96 \pm 6.67$ & 13.77 & $69.96 \pm 16.56^{++}$ & 8.58 & $63.07 \pm 18.25^{++}$ & 22.35 \\
\hline Lens esculenta $\mathrm{L}$. & 56 & $95.25 \pm 5.41$ & 11.92 & $88.25 \pm 10.40^{++}$ & 11.70 & $90.03 \pm 8.22^{++}$ & 23.62 \\
\hline Phaseolus vulgaris L. & 56 & $91.71 \pm 6.51$ & 12.72 & $79.30 \pm 15.48^{++}$ & 8.97 & $84.03 \pm 14.18^{++}$ & 21.69 \\
\hline Glycine max Merr. & 306 & $91.87 \pm 7.29$ & 11.09 & $77.91 \pm 13.64^{++}$ & 12.78 & $80.56 \pm 13.12^{++}$ & 23.87 \\
\hline \multicolumn{8}{|c|}{ Industrial crops } \\
\hline Brassica napus L. & 44 & $94.72 \pm 6.08$ & 13.27 & $85.79 \pm 8.93^{+++}$ & 8.45 & $85.31 \pm 8.29^{+++}$ & 21.72 \\
\hline Helianthus annuиs L. & 53 & $91.92 \pm 6.63$ & 13.33 & $92.72 \pm 7.09$ & 9.74 & $90.54 \pm 10.42$ & 23.07 \\
\hline Nicotiana tabacum L. & 117 & $97.02 \pm 5.38$ & 13.00 & $93.64 \pm 12.00$ & 8.82 & $90.76 \pm 13.29^{++}$ & 21.82 \\
\hline Linum usitatissimum L. & 67 & $96.71 \pm 4.71$ & 12.22 & $90.86 \pm 5.19^{+++}$ & 11.00 & $89.13 \pm 10.09^{++}$ & 23.22 \\
\hline \multicolumn{8}{|c|}{ Vegetables } \\
\hline Brassica oleracea $\mathrm{L}$. & 48 & $89.00 \pm 8.03$ & 13.64 & $84.27 \pm 17.78$ & 9.00 & $81.85 \pm 17.78^{+}$ & 22.64 \\
\hline Lactuca sativa $\mathrm{L}$. & 177 & $85.18 \pm 8.81$ & 13.40 & $75.83 \pm 11.60^{++}$ & 8.97 & $72.40 \pm 14.20^{++}$ & 22.37 \\
\hline Cucumis sativus L. & 68 & $99.26 \pm 2.15$ & 13.54 & $97.88 \pm 3.22$ & 9.37 & $97.94 \pm 2.80$ & 22.91 \\
\hline $\begin{array}{l}\text { Lycopersicon esculentum } \\
\text { Miller }\end{array}$ & 63 & $92.50 \pm 6.67$ & 11.30 & $85.34 \pm 10.01^{++}$ & 12.21 & $84.04 \pm 10.72^{++}$ & 23.51 \\
\hline Capsicum aпnиит $\mathrm{L}$. & 30 & $90.66 \pm 6.91$ & 13.30 & $87.76 \pm 7.27$ & 8.13 & $87.13 \pm 6.98$ & 21.43 \\
\hline
\end{tabular}

${ }^{+} p \leq 0.05,{ }^{++} p \leq 0.01,{ }^{+++} p \leq 0.001, \mathrm{SD}$-standard deviation $[\%]$ 
$\mathrm{T}$ a

Seed longevity of plant species predicted after real long-term storage in National Gene bank of Bulgaria

\begin{tabular}{|c|c|c|c|c|c|c|c|c|}
\hline Crops/Species & $\begin{array}{l}\text { Number } \\
\text { of access. }\end{array}$ & $\begin{array}{c}\text { Seed } \\
\text { moisture } \\
\text { content } \\
{[\%]}\end{array}$ & $\begin{array}{c}\text { Total } \\
\text { storage } \\
\text { period } \\
\text { [year] }\end{array}$ & $\mathrm{K}_{\mathrm{i}}$ & $1 / \sigma$ & $\begin{array}{c}\sigma \\
{[\text { year] }}\end{array}$ & $\begin{array}{c}\mathrm{P}_{10 \%} \\
\text { [year] }\end{array}$ & $\begin{array}{l}\mathrm{P}_{50 \%} \\
\text { [year] }\end{array}$ \\
\hline \multicolumn{9}{|c|}{ Cereals } \\
\hline Avena sativa $\mathrm{L}$. & 457 & $6.22 \pm 0.27$ & 23.12 & 1.761 & -0.002 & 500.00 & 338.5 & 880.00 \\
\hline Hordeum vulgare L. & 1195 & $6.85 \pm 0.21$ & 22.78 & 1.509 & -0.003 & 333.33 & 179.0 & 502.67 \\
\hline Secale cereale $\mathrm{L}$. & 35 & $7.09 \pm 0.37$ & 23.48 & 1.544 & -0.027 & 37.03 & 20.55 & 55.85 \\
\hline Sorghum vulgare L. & 99 & $6.59 \pm 0.26$ & 24.13 & 1.241 & -0.015 & 66.66 & 28.33 & 82.67 \\
\hline X Triticosecale Wittm. & 52 & $6.91 \pm 0.50$ & 24.00 & 1.327 & -0.020 & 50.00 & 22.85 & 66.30 \\
\hline Zea mays $\mathrm{L}$ & 364 & $7.07 \pm 0.32$ & 23.49 & 1.552 & -0.011 & 90.90 & 50.81 & 141.00 \\
\hline Triticum aestivum $\mathrm{L}$. & 1547 & $6.91 \pm 0.26$ & 23.03 & 1.695 & -0.002 & 500.00 & 318.5 & 847.00 \\
\hline Triticum durum Desf. & 389 & $7.09 \pm 0.42$ & 27.29 & 1.675 & -0.009 & 111.11 & 69.44 & 186.00 \\
\hline \multicolumn{9}{|c|}{ Cereal grasses } \\
\hline Dactylis glomerata L. & 55 & $6.12 \pm 0.34$ & 22.78 & 1.027 & -0.009 & 111.11 & 39.89 & 114.00 \\
\hline Bromus inermis L. & 37 & $5.84 \pm 0.16$ & 21.13 & 1.295 & -0.004 & 250.00 & 111.2 & 323.50 \\
\hline $\begin{array}{l}\text { Festuca arundinacea } \\
\text { Schreb. }\end{array}$ & 34 & $5.78 \pm 0.22$ & 22.97 & 1.763 & -0.023 & 43.47 & 29.47 & 76.61 \\
\hline \multicolumn{9}{|c|}{ Legumes } \\
\hline Vicia faba L. & 57 & $6.91 \pm 0.50$ & 21.94 & 1.732 & -0.012 & 83.33 & 54.92 & 144.25 \\
\hline Vicia sativa $\mathrm{L}$. & 131 & $6.81 \pm 0.28$ & 24.16 & 1.275 & -0.015 & 66.67 & 29.13 & 84.93 \\
\hline Lathyrus sativus L. & 65 & $6.99 \pm 0.37$ & 23.75 & 1.502 & -0.019 & 52.63 & 28.11 & 79.00 \\
\hline Cicer arietinum $\mathrm{L}$. & 37 & $5.94 \pm 0.51$ & 23.91 & 1.525 & -0.009 & 111.11 & 60.56 & 169.33 \\
\hline Arachis hypogaea L. & 54 & $3.37 \pm 0.28$ & 22.35 & 1.347 & -0.049 & 20.41 & 9.49 & 28.51 \\
\hline Lens esculenta L. & 56 & $6.84 \pm 0.10$ & 23.62 & 1.575 & -0.016 & 62.50 & 35.94 & 98.38 \\
\hline Phaseolus vulgaris L. & 56 & $7.25 \pm 0.25$ & 21.69 & 1.293 & -0.020 & 50.00 & 22.20 & 64.60 \\
\hline Glycine $\max$ Merr. & 306 & $5.95 \pm 0.52$ & 23.87 & 1.261 & -0.022 & 45.45 & 19.64 & 57.27 \\
\hline \multicolumn{9}{|c|}{ Industrial crops } \\
\hline Brassica napus L. & 44 & $4.56 \pm 0.25$ & 21.72 & 1.567 & -0.028 & 35.71 & 20.25 & 55.93 \\
\hline Nicotiana tabacum L. & 117 & $3.30 \pm 0.06$ & 21.82 & 1.877 & -0.026 & 38.46 & 28.92 & 72.15 \\
\hline Helianthus annuus L. & 53 & $3.94 \pm 0.22$ & 23.07 & 1.429 & -0.003 & 333.33 & 166.60 & 476.00 \\
\hline Linum usitatissimum L. & 67 & $4.59 \pm 0.29$ & 23.22 & 1.780 & -0.026 & 38.46 & 26.50 & 68.42 \\
\hline \multicolumn{9}{|c|}{ Vegetables } \\
\hline Brassica oleracea L. & 48 & $4.59 \pm 0.17$ & 22.64 & 1.219 & -0.014 & 71.43 & 29.86 & 87.00 \\
\hline Capsicum annuum $\mathrm{L}$. & 30 & $4.53 \pm 0.09$ & 21.43 & 1.310 & -0.009 & 111.11 & 50.11 & 145.44 \\
\hline $\begin{array}{l}\text { Lycopersicon } \\
\text { esculentum Miller }\end{array}$ & 63 & $4.81 \pm 0.36$ & 23.51 & 1.379 & -0.019 & 52.63 & 25.21 & 72.53 \\
\hline Lactuca sativa L. & 177 & $4.22 \pm 0.37$ & 22.37 & 1.025 & -0.021 & 47.62 & 17.10 & 48.76 \\
\hline Cucumis sativus L. & 68 & $4.69 \pm 0.20$ & 22.91 & 2.390 & -0.018 & 55.56 & 64.44 & 132.72 \\
\hline
\end{tabular}

$\mathrm{K}_{\mathrm{i}}$ - Probit value of initial seed viability; $1 / \sigma$ - measure of seed deterioration in storage; $\sigma$ - standard deviation of seed death in storage; $\mathrm{P}_{10 \%}$ - time in years for seed viability reduction with $10 \% ; \mathrm{P}_{50 \%}-$ seed half-life or measure of time to $50 \%$ seed viability in storage 
L., and 250 years for Bromus inermis L. Generally, $68.75 \%$ of the evaluated species are characterized with a short life span after the real long-term storage in National Genebank of Bulgaria ( $\sigma<100$ years) (Table 2). Longevity can also be described by determining the time taken for viability to fall to $50 \%$ $\left(\mathrm{P}_{50 \%}\right)$. Walters et al. (2005b) reported that large families as Asteraceae, Fabaceae, Poaceae, and Solanaceae contained species with wide-ranging $\mathrm{P}_{50 \%}$ values, that is the time required for germination to decrease to half the initial value. Similarly, Probert et al. (2009) reported wide variation in $\mathrm{P}_{50 \%}$ between families, as well as within some families, but relatively little variation in longevity among genera within those families. Differences in seed longevity between cultivars and wild types of crops have been reported for diverse taxa (Walters et al. 2005b; Ellis \& Hong 2007). In the presented study, there was wide variation between crops in the time taken for viability to fall to $50 \%$. The calculated value was the lowest for peanuts (28.51 years), following by lettuce (48.76 years), rye (55.85 years), rapeseeds (55.93 years) and soybean (57.27 years). The crops can be classified into groups having high longevity $(300<\sigma>1000)$ - oats, bread wheat, barley and sunflower have the highest $\mathrm{P}_{50 \%}$ values, respectively 880, 847, 502.67 and 476 years. The species with similar $\sigma$ values are differentiated by $\mathrm{P}_{50 \%}$ values.

Seed aging during storage is an inevitable phenomenon, but the degree and speed of decline in seed quality depends strongly, beside storage conditions, on plant species stored and initial seed quality (Elias \& Copeland 1994; Balešević-Tubić et al. 2005), as well as on the seed genetic traits (Malenčić et al. 2003). Milošević et al. (1996) also suggested that seed longevity is genetically determined, and that significant differences exist among cultivars of same crops in their ability to maintain quality during storage (Balešević-Tubić et al. 2010). Seed structure and climate of origin are also known genetic factors related to seed longevity (Probert et al. 2009).

As mentioned before, a decrease in seed viability of $10 \%$ could induce genetic shifts in heterogeneous seed accessions (Stoyanova 1991; 1992; 1996). The safe storage time $\left(\mathrm{P}_{10 \%}\right)$ or the time for seed viability reduction of $10 \%$ was calculated using the viability equation proposed by Ellis and Roberts
(1980). According to the results presented in Table 2 , plant species described with shortest longevity (Arachis hypogaea L., Lactuca sativa L., Glycine max Merr., Brassica napus L., Secale cereale L. and $X$ Triticosecale Wittm.) should not be monitored later than 10-20 years from the beginning of storage. The safe storage time for Sorghum vulgare L., Festuca arundinacea Schreb., Vicia sativa L., Lathyrus sativus L., Nicotiana tabacum L., Linum usitatissimum L., Brassica oleracea L. and Lens esculenta L. is prolonged to 25-35 years, while for Dactylis glomerata L., Zea mays L., Triticum durum Desf., Vicia faba L., Cicer arietinum L., Capsicum annuum L. and Cucumis sativus L. is 40-60 years or more. When safe storage is longer than 100 years, the risk of losses in time is limited (Stoyanova 2001). The predicted storage times for Bromus inermis L., Helianthus annuus L. and Hordeum vulgare L. were above 100 years, while for plant species described with longest longevity (Avena sativa L. and Triticum aestivum L.) was above 300 years.

However, it should be pointed out that the Probit analysis for modelling was made on a storage period $\left(-18^{\circ} \mathrm{C}\right)$ of around 20 years. This is a rather short time for such conditions, and therefore, future investigations need to be made in this area. On the other hand, Nagel et al. (2010) mentioned that viability equation can forecast a longevity tendency, but the behaviour of a specific genotype depends on more factors than moisture content, storage temperature and initial viability. Therefore, as a guarantee for prevention of changes, the predictions should be carried out on plant groups according to the conditions for compatibility in each species. Moreover, seed viability monitoring should be done individually, and should not be monitored selectively because there was a large variation of viability among accessions.

\section{CONCLUSIONS}

The results obtained from the monitoring tests indicate that the storage conditions in the National Seed Gene bank of Bulgaria are suitable for the preservation of the investigated species. Only two species (Arachis hypogaea L. and Glycine max Merr.) showed significantly decreased germination 
percentages when compared with the germination percentages before storage, but the damages leading to loss of accessions were not observed. However, viability differs greatly between species and within a species, as does the response to storage. Seed longevity calculated as $\sigma$ values varied from 20.41 to 500 years. Generally, $68.75 \%$ of the evaluated species are characterized with short life span after real long-term storage in National Gene bank of Bulgaria $(\sigma<100$ years). The longest storability had bread wheat, oats, barley and sunflower $(\sigma>300$ years). The predicted time of safe storage $\left(\mathrm{P}_{10 \%}\right)$ for peanuts, lettuce, rye, triticale, rapeseeds and soybean was $10-20$ years. The safe storage time for sorghum, tall fescue, common vetch, grass pea, tobacco, flax, rapeseed and lentil was prolonged to 25-35 years, while for orchard grass, maize, durum wheat, faba bean, chickpea, pepper and cucumber was $40-60$ years or more. The predicted storage times for smooth brome grass, sunflower and barley were above 100 years, while for plant species described with longest longevity (oats and bread wheat) was above 300 years. The presented results are a useful tool for the monitoring of gene bank storage and the prediction of regeneration needs in the National Gene bank of Bulgaria.

Acknowledgements. I would like to acknowledge Prof. Siyka Stoyanova for her long standing work as a head of the National Gene bank of Bulgaria. Due to her dedication, we have been able to achieve excellent results in the seed gene bank management; seed processing and gene bank technology, ex situ conservation and monitoring of genetic integrity; database development. I want to also thank all the staff members who have been involved in the seed storage processing and germination testing at the National Gene bank of Bulgaria since 1984.

\section{REFERENCES}

BALEŠEVIĆ-TUBIĆ, S. - MALENČIĆ, Đ. - TATIĆ, M. - MILADINOVIĆ, J. 2005. Influence of aging process on biochemical changes in sunflower seed. In Helia, vol. 28, no. 42, pp. 107-114. DOI: 10.2298/ HEL $0542107 \mathrm{~B}$

BALEŠEVIĆ-TUBIĆ, S. - TATIĆ, M. - ĐORĐEVIĆ, V. NIKOLIĆ, Z. - ĐUKIĆ, V. 2010. Seed viability of oil crops depending on storage conditions. In Helia, vol. 33, no. 52, pp. 153-160. DOI: 10.2298/HEL1052153B BENKOVÁ, M. - ŽÁKOVÁ, M. 2008. Comparison of germinability selected seeds after ten years storage. In Agriculture (Pol'nohospodárstvo), vol. 54, no. 3, pp. 89-98.

CHIN, H.F. 1994. Seedbanks: conserving the past for the future. In Seed Science and Technology, vol. 22, pp. 385-400.

COOLBEAR, P. 1995. Mechanism of seed deterioration. In BASRA, A.S. (Ed). Seed Quality: Basic Mechanisms and Agricultural Implications. New York : Food Product Press, pp. 223-277.

COPELAND, L.O. - McDONALD, M.B. 2001. Principles of seed science and technology. 4th. Massachusetts, USA : Kluwer Academic Publishers, pp. 190-230.

ELIAS, S.G. - COPELAND, L.O. 1994. The effect of storage conditions on canola (Brassica napus L.) seed quality. In Journal of Seed Technology, vol. 18, pp. 21-22.

ELLIS R.H. - ROBERTS E.H. 1980. Improved equations for the prediction of seed longevity. In Annals of Botany, vol. 45, pp. 13-30.

ELLIS, R.H. - HONG, T.D. - ROBERTS, E.H. 1985 a. Handbooks for genebanks 2. Handbook of seed technology for genebanks Vol. I: Principles and methodology. Rome, Italy: International Boards for Plant Genetic Resources, 210 p., ISBN-10: 92-9043-118-0

ELLIS, R.H. - HONG, T.D. - ROBERTS, E.H. 1985 b. Handbooks for genebanks 3. Handbook of seed technology for genebanks, Vol. II : Compendium of specific germination information and test recommendations. Rome, Italy: International Boards for Plant Genetic Resources, 456 p., ISBN-10: 92-9043-119-9

ELLIS, R.H. - HONG, T.D. 2007. Quantitative response of the longevity of seed of twelve crops to temperature and moisture in hermetic storage. In Seed Science and Technology, vol. 35, pp. 432-444.

ENGELS, J.M.M. - VISSER, L. 2003. A guide to effective management of germplasm collections. International Plant Genetic Resources Institute Handbook for Genebanks No 6. International Plant Genetic Resources Institute, Rome, Italy. Available at http://cropgenebank.sgrp.cgiar.org/images/file/learning_space/genebankmanual6.pdf.

FAO. 2014. Genebank standards for plant genetic resources for food and agriculture. Available at http:// www.fao.org/3/a-i3704e.pdf.

FAO. 1994. Genebank Standards. 1994. Food and Agriculture Organization of the United Nations, Rome, International Plant Genetic Resources Institute, Rome. Available at ftp://ftp.fao.org/docrep/fao/meeting/015/ aj680e.pdf.

FU, Y.B. - AHMED, Z. - DIEDERICHSEN, A. 2015. Towards a better monitoring of seed ageing under ex situ seed conservation. In Conservation Physiology, vol. 3, pp. 1-16. DOI:10.1093/conphys/cov026

GROOT STEVEN, P.C. - LIESBETH de GROOT - KODDE, J. - van TREUREN R. 2015. Prolonging the longevity of ex situ conserved seeds by storage under an- 
oxia. In Plant Genetic Resources, vol. 13, pp. 18-26. DOI: $10.1017 / \mathrm{S} 1479262114000586$

HANSON, J. 1985. Practical Manuals for Genebanks. Rome : IBPGR, pp. 115.

HO-SUN, L. - YOUNG-AH, J. - YOUNG-YI, L. - SOKYOUNG, L. - YEON-GYU, K. 2013. Comparison of seed viability among 42 species stored in a genebank. In Korean Journal Crop Science, vol. 58, no. 4, pp. 432-438. DOI: http: 10.7740/kjcs.2013.58.4.432

HONG, T.D. - LININGTON, S. - ELLIS, R.H. 1998. Appendix 1. List of viability constants for use in the viability equation of Ellis and Roberts (1980a) and predicted seed storage longevity. In HONG, T.D. LININGTON, S. - ELLIS, R.H. (Eds) Compendium of information on seed storage behavior, vol. 2, I-Z, Kew : The Royal Gardens, Kew, pp. 881-882.

ISTA, 1985. International rules for seed testing. In Seed Science and Technology, vol. 13, pp. 299-355.

LU, X. - CHEN, X. - CUI, C. 2004. Germination ability of seeds of 23 crop plant species after a decade of storage in the National Gene Bank of China. In Plant Genet Resources Newsletter, vol. 139, pp. 42-46.

MALENČIĆ, Đ. - POPOVIĆ, M. - MILADINOVIĆ, J. 2003. Stress tolerance parameters in different genotypes of soybean. In Biology Plantarum, vol. 46, pp. 141-143. DOI: 10.1023/A:1022384600538

MILOŠEVIĆ, M. - MIHALJEV, I. - DOKIĆ, P. ĆIROVIĆ, M. 1996. Seed science, Feljton, Novi Sad, pp. 148-151.

NAGEL, M. - BÖRNER, A. 2010. The longevity of crop seeds stored under ambient conditions. In Seed Science Research, vol. 20, no. 1, pp. 1-12. DOI: 10.1017/ S0960258509990213

NAGEL, M. - VOGEL, H. - LANDJEVA, S. - BUCK-SORLIN, G. - LOHWASSER, U. - SCHOLZ, U. - BÖRNER, A. 2009. Seed conservation in ex situ genebanks - genetic studies on longevity in barley. In Euphytica, vol. 170, pp. 5-14. DOI: 10.1007/s 10681-009-9975-7

NAGELL, M. - ARIF, M.A.R. - ROSENHAUER, M. BÖRNER, A. 2010. Longevity of seeds - intraspecific differences in the Gatersleben genebank collections. In Tagung der Vereinigung der Pflanzenzüchter und Saatgutkauflfleute Österreichs, pp. 179-182. ISBN 978-3-902559-37-1

PARZIES, H.K. - SPOOR, W. - ENNOS, R.A. 2000. Genetic diversity of barley landrace accessions (Hordeum vulgare ssp. vulgare) conserved for different lengths of time in ex situ gene banks. In Heredity, vol. 84, pp. 476-486.

PÉREZ-GARCÍA，F. - GÓMEZ-CAMPO, C. - ELLIS, R.H. 2009. Successful long-term ultra-dry storage of seed of 15 species of Brassicaceae in a genebank: variation in ability to germinate over 40 years and dormancy. In Seed Science and Technology, vol. 37, no. 3, pp. 640-649 (10). DOI: 10.15258/sst.2009.37.3.12

PITA, J.M. - PERE-GARCIA, F. - ESCUDERO, A. - de la CUADRA, C. 1998. Viability of Avena sativa L. seeds after 10 years of storage in base collection. In Field Crop Research, vol. 55, pp.183-187.

PROBERT, R.J. - DAWS, M.I. - HAY, F.R. 2009. Ecological correlates of ex situ seed longevity: a compar- ative study on 195 species. In Annals of Botany, vol. 104, pp. 57-69. DOI: 10.1093/aob/mcp082

RAJJOU, L. - DEBEAUJON, I. 2008. Seed longevity: survival and maintenance of high germination ability of dry seeds. In Crop Research Biology, vol. 331, pp. 796-805. DOI: 10.1016/j.crvi.2008.07.021

ROBERTS, E.H. 1973. Predicting the storage life of seeds. In Seed Science and Technology, vol. 1, pp. 499-514.

ROBERTS, E.H. - ELLIS, R.H. 1982. Physiological, ultra structural and metabolic aspects of seed viability. In KHAN, A.A. (Ed) The Physiology and Biochemistry of Seed Development Dormancy and Germination. Amsterdam : Elsevier Biomedical Press, pp. 465-485.

RUIZ, M. - MARTIN, I. - CUADRA, C. 1999. Cereal seed viability after 10 years of storage in active and base germplasm collections. In Field Crops Research, vol. 64, pp. 229-236. DOI: 10.1016/S03784290(99)00044-1

SAI BABU, K.G. - HUSAIAI, S.H. - MURALIMONAN, R.B. 1983. Effect of moisture and container on the storability of paddy seed under ambient conditions of Hyderabad. In Seed Research, vol. 11, no.1, pp. 71-73.

SASTRY, D.V.S.S.R. - UPADHYAYA, H.D. - GOWDA, C.L.L. 2008. Seed viability of active collections in ex-situ genebanks: an analysis of sorghum germplasm conserved at ICRISAT genebank. In An Open Access Journal published by ICRISAT, vol. 6, pp. 1-8.

SMITH, R.D. - DICKIE, J.D. - LININGTON, S.H. PRITCHARD, H.W. - PROBERT, R.J. 2003. Seed Conservation: Turning Science into Practice. Kew : Royal Botanic Gardens, Kew. 1023 pp.

STOYANOVA, S.D. 2001. Ex situ conservation in the Bulgarian genebank. I. Effect of storage. In $P G R$ Newsletter, vol. 128, pp. 68-76.

STOYANOVA, S.D. 1991. Genetic shifts and variation induced by seed ageing. In Seed Science and Technology, vol. 19, pp. 363-371.

STOYANOVA, S.D. 1992. Effect of seed ageing and regeneration on the genetic composition of wheat. In Seed Science and Technology, vol. 20, pp. 489-496.

STOYANOVA, S.D. 1996. Variation of gliadins in wheat cultivars associated with seed survival and multiplication. In Seed Science and Technology, vol. 24, pp. $115-126$.

THU-PHUONG, N. - KEIZER, P. - VAN EEUWIJK, F. - SMEEKENS, S. - BENTSINK, L. 2012. Natural variation for seed longevity and seed dormancy are negatively correlated in Arabidopsis. In Plant Physiology, vol. 160, pp. 2083-2092. DOI: 10.1104/ pp. 112.206649

VAN TREUREN, R. - de GROOT, E.C. - van HINTUM, J.L. 2013. Preservation of seed viability during 25 years of storage under standard genebank conditions. In Genetic Resources Crop Evaluation, vol. 60, pp. 1407-1421. DOI: 10.1007/s 10722-012-9929-0

WALDREN, S. - MARTIN, J.R. - CURTIS, T.G.F. O'SULLIVAN, A. 2000. Genebanks and biodiversity conservation: the Irish threatened plant genebank project. In RUSHTON, B.S. (Ed) Biodiversity: the 
Irish dimension. Dublin : Royal Irish Academy, pp. 135-147.

WALSH, D.G.F - WALDREN, S. - MARTIN, J.R. 2003. Monitoring seed viability of fifteen species after storage in the Irish threatened plant genebank. In Biology and Environment: Proceedings of The Royal Irish Academy, vol. 103B, no. 2, pp. 59-67.

WALTERS, C. 1998. Understanding the mechanisms and kinetics of seed aging. In Seed Science Research, vol. 8, pp. 223-244. DOI: 10.1017/S096025850000413X
WALTERS, C. - HILL, L.M. - WHEELER, L.J. $2005 \mathrm{a}$. Dying while dry: kinetics and mechanisms of deterioration in desiccated organisms. In Integrative and Comparative Biology, vol. 45, pp. 751-758. DOI: 10.1093/icb/45.5.751

WALTERS, C. - WHEELER, L.M. - GROTENHUIS, J.M. 2005b: Longevity of seeds stored in a genebank: species characteristics. In Seed Science Research, vol. 15, pp. 1-20. DOI: http://dx.doi.org/10.1079/ SSR2004195 